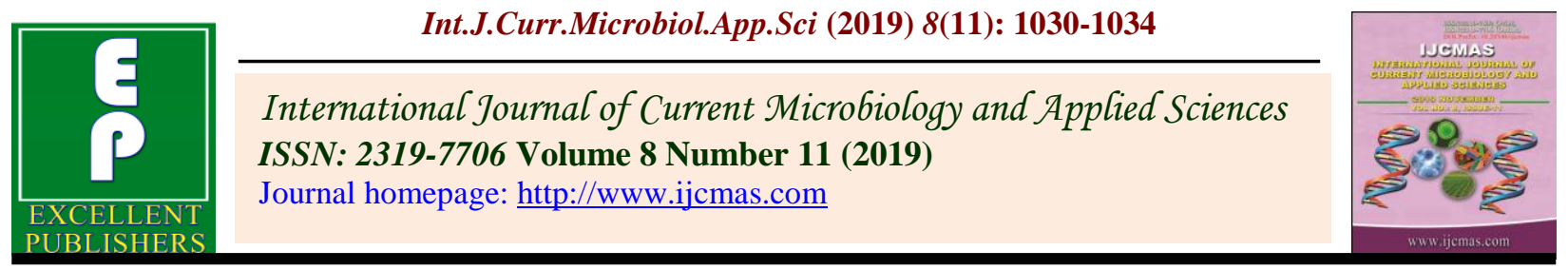

Original Research Article

https://doi.org/10.20546/ijcmas.2019.811.121

\title{
Effect of Organic Manures on Growth, Yield and Quality of Mango Ginger (Curcuma amada Roxb.) in the Gangetic Alluvial Plains of West Bengal
}

\author{
Anupam Pariari $^{1}$, C.S. Karthik ${ }^{2}$ and Sarthak Bhattacharya ${ }^{2 *}$
}

${ }^{1}$ AICRP on Spices, ${ }^{2}$ Department of Plantation, Spices, Medicinal and Aromatic Crops, Bidhan Chandra KrishiViswavidyalaya, Mohanpur, Nadia, India

*Corresponding author

\section{Keywords}

Mangoginger, Organic manures, Yield

Article Info

Accepted:

10 October 2019

Available Online:

10 November 2019

\section{A B S T R A C T}

The experiment was carried out at Horticultural Research Farm, Barajaguli, BCKV, Mohanpur, Nadia, West Bengal during the years 2016-17 and 2017-18. The rhizomes were planted during middle of May in $3.0 \times 2.0 \mathrm{~m}$ plot at $30 \times 25 \mathrm{~cm}$ spacing with three replications. Four organic manures (Farm yard manure, Poultry manure, Mustard cake and Vermicompost) with single (25t/ha, 1t/ha, $0.75 \mathrm{t} / \mathrm{ha}$ and $2.5 \mathrm{t} / \mathrm{ha})$ and double $(50 \mathrm{t} / \mathrm{ha} .2 \mathrm{t} / \mathrm{ha}$, $1.5 \mathrm{t} / \mathrm{ha}$ and $5 \mathrm{t} / \mathrm{ha}$ ) doses along with control which results in 9 treatment combinations were applied. The maximum plant height $(94.55 \mathrm{~cm})$, number of tillers/plant (5.73) and number of leaves/plant (12.16) were observed by application of Poultry manure @ $2 \mathrm{t} / \mathrm{ha}\left(\mathrm{T}_{4}\right)$. Highest yield/ha $(32.88 \mathrm{t} / \mathrm{ha})$ was also noticed in Poultry manure @ 2 t/ha $\left(\mathrm{T}_{4}\right)$ followed by Mustard cake @ $0.75 \mathrm{t} / \mathrm{ha}\left(\mathrm{T}_{5}\right)$. The highest curcumin percentage $(1.34 \%)$ and oleoresin percentage $(6.52 \%)$ were noticed in Vermicompost @ $5 \mathrm{t} / \mathrm{ha}\left(\mathrm{T}_{8}\right)$ over control $(0.48 \%$ and $4.66 \%) \mathrm{T}_{9}$.

\section{Introduction}

The genus Curcuma, belonging to the family Zingiberaceae, comprises over 80 species of rhizomatous herbs that are adapted to environments from sea level to elevations as high as 2000 min the Western Ghats and Himalayas The genusis originated in the IndoMalayan region and widely distributed in the tropics of Asia to Africa and Australia (Sasikumar,2005). Mangoginger (Curcuma amada Roxb.) is an important member of this genus, is a unique spice, which morphologically resembles the ginger (Zingiber officinale) but, it imparts mango (Mangifera indica) flavour. Mango flavor is mainly attributed to car-3-eneandcis-ocimene (Achut et al., 1984 and Rao et al., 1989). Mango ginger is used the rapeutically as a carminative and stomachic and topically for contusions and sprains (Kirtikar and Basu, 1984; Nadkarni, 1954; Rao et al., 1989). 
Organic manures provide all the nutrients that are required by the plant, maintains the $\mathrm{C}: \mathrm{N}$ ratio in the soil, thereby improves the yield. Very meagre literature is available on effect of organic manures in mango ginger. Therefore, the present investigation was undertaken to study the efficacy of different organic manures in Mango ginger.

\section{Materials and Methods}

The present experiment was undertaken during the middle of May for two consecutive years i.e., 2016-17 and 2017-18 at Horticultural Research Farm, Barajaguli, Bidhan Chandra Krishi Viswavidyalaya, Mohanpur, Nadia, West Bengal $\left(23.5^{\circ} \mathrm{N}\right.$ and $89^{\circ} \mathrm{E}$ longitude, with an altitude of $9.75 \mathrm{~m}$ above the mean sea level).

The soil of the experiment field was Entisol with sandy clay loam texture $(54.25 \%$ sand, $30.20 \%$ silt and $14.30 \%$ clay), slightly acidic to neutral in reaction ( $\mathrm{pH}$ 6.7) with good water holding capacity, well drained with moderate soil fertility status. The experiment was conducted in Randomized block design with nine treatments replicated thrice. There were nine treatments including control viz., $\mathrm{T}_{1^{-}}$ Farm yard manure @ 25t/ha, T $2^{-}$Farm yard manure @ 50t/ha, T $3^{-}$Poultry manure @ 1t/ha, T $4^{-}$Poultry manure @ 2t/ha, T $5^{-}$ Mustard cake@0.75t/ha, T6- Mustard cake @ 1.5t/ha, $\mathrm{T}_{7}$-Vermicompost@ 2.5t/ha, $\mathrm{T}_{8^{-}}$ Vermicompost@ 5t/ha and $\mathrm{T}_{9^{-}}$Control.

Rhizomes of Mango ginger var. Nadia (Krishnagar) local were sown with a spacing of $30 \times 25 \mathrm{~cm}$ in a plot size of $6 \mathrm{~m}^{2}$. The data recorded on various parameters were subjected to statistical analysis as per the procedure suggested by Gomez and Gomez, 1984.

\section{Results and Discussion}

The growth, yield and quality parameters of Mango ginger (Curcuma amada Roxb) recorded were shown significant differences among the treatments. The effect of organic manures on various growth, yield and quality parameters of Mango ginger are briefly discussed.

\section{Vegetative parameters}

A perusal of Table 1 indicated significant variations in plant height due to application of organic manures observed at maturity stage. Maximum plant height $(94.55 \mathrm{~cm})$ was recorded by application of Poultry manure @ $2 \mathrm{t} / \mathrm{ha}\left(\mathrm{T}_{4}\right)$ followed by $\mathrm{T}_{3}(87.26 \mathrm{~cm})$ and the lowest recorded in Control $(61.38 \mathrm{~cm})$ i.e. $\mathrm{T}_{9}$. Data presented in Table 1 clearly indicated that there was significant variation with respect to number of tillers per plant during both the years. Maximum number of tillers per plant (5.73) were noticed in the plot applied with Poultry manure @ 2 t/ha $\left(\mathrm{T}_{4}\right)$ followed by Poultry manure @ 1t/ha (4.86) $\mathrm{T}_{3}$.

Minimum number of tillers per plant was noticed from control (1.93) plots. Data presented in Table 1 showed significant variation with respect to number of leaves per plant, leaf length, leaf breadth and leaf area observed at maturity stage. Maximum number of leaves per plant, leaf length, leaf breadth and leaf area was recorded in $\mathrm{T}_{4}(12.16,64.07$ $\mathrm{cm}, 16.10 \mathrm{~cm}$ and $686.99 \mathrm{~cm}^{2}$ respectively) followed by $\mathrm{T}_{3}(11.43,60.65 \mathrm{~cm}, 15.93 \mathrm{~cm}$ and $643.45 \mathrm{~cm}^{2}$ respectively).

Minimum number of leaves per plant, leaf length, leaf breadth and leaf area were noticed in control i.e. $\mathrm{T}_{9}(8.19,35.18 \mathrm{~cm}, 11.43 \mathrm{~cm}$ and $267.80 \mathrm{~cm}^{2}$ ) plots. Adesodun et al., (2005) had found that application of poultry manure to soil increased soil organic matter, $\mathrm{N}$ and $\mathrm{P}$ and aggregate stability.

\section{Yield and yield attributing parameters}

The data on yield and yield attributing parameters viz. length of clumps $(\mathrm{cm})$, number 
of mother rhizome, number of primary finger, number of secondary finger, yield per plant $(\mathrm{g})$ and yield per hectare $(\mathrm{t} / \mathrm{ha})$ presented in Table 2. These yield and yield attributing parameters showed significant variations due to application of organic manures. The application of Poultry manure @ 2 t/ha $\left(\mathrm{T}_{4}\right)$ effectively increase length of clumps $(23.10$ $\mathrm{cm})$, number of mother rhizome (2.03), number of primary finger (6.18), number of secondary finger (16.11), yield per plant $(411.02 \mathrm{~g})$ and yield per hectare (32.88 t/ha), which was followed by Poultry manure @ 1 $\mathrm{t} / \mathrm{ha}\left(\mathrm{T}_{3}\right)$ treatment $(22.63 \mathrm{~cm}, 1.82,5.74$, $15.87, \quad 397.88 \mathrm{~g}$ and $31.83 \mathrm{t} / \mathrm{ha}$ respectively).The poultry manure could have supplied micronutrients which is essential for ginger growth and yield. Stirling (1989) and stirling and Nikulin (1998) also recorded the highest yield of ginger with poultry manure.

\section{Yield and yield attributing parameters}

The data on yield and yield attributing parameters viz. length of clumps $(\mathrm{cm})$, number of mother rhizome, number of primary finger, number of secondary finger, yield per plant $(\mathrm{g})$ and yield per hectare ( $t / h a)$ presented in Table 2 . These yield and yield attributing parameters showed significant variations due to application of organic manures. The application of Poultry manure @ $2 \mathrm{t} / \mathrm{ha}\left(\mathrm{T}_{4}\right)$ effectively increase length of clumps (23.10 $\mathrm{cm})$, number of mother rhizome (2.03), number of primary finger (6.18), number of secondary finger (16.11), yield per plant $(411.02 \mathrm{~g})$ and yield per hectare (32.88 t/ha), which was followed by Poultry manure @ 1 t/ha $\left(\mathrm{T}_{3}\right)$ treatment $(22.63 \mathrm{~cm}, 1.82,5.74$, $15.87,397.88 \mathrm{~g}$ and $31.83 \mathrm{t} / \mathrm{ha}$ respectively).

The poultry manure could have supplied micronutrients which is essential for ginger growth and yield. Stirling (1989) and stirling and Nikulin (1998) also recorded the highest yield of ginger with poultry manure.

Table.1 Effect of organic manures on vegetative parameters of Mango ginger (Curcuma amada Roxb.)

\begin{tabular}{|c|c|c|c|c|c|c|}
\hline Treatments & $\begin{array}{c}\text { Plant } \\
\text { height } \mathbf{( c m )}\end{array}$ & $\begin{array}{c}\text { No. of } \\
\text { tillers per } \\
\text { plant }\end{array}$ & $\begin{array}{c}\text { No. of } \\
\text { leaves per } \\
\text { plant }\end{array}$ & $\begin{array}{c}\text { Leaf } \\
\text { length } \\
(\mathbf{c m})\end{array}$ & $\begin{array}{c}\text { Leaf } \\
\text { breadth } \\
(\mathbf{c m})\end{array}$ & $\begin{array}{c}\text { Leaf area } \\
\left(\mathbf{c m}^{\mathbf{2}}\right)\end{array}$ \\
\hline $\mathbf{T}_{\mathbf{1}}$ & 78.94 & 3.91 & 9.74 & 46.74 & 14.81 & 461.01 \\
\hline $\mathbf{T}_{\mathbf{2}}$ & 81.73 & 4.12 & 9.98 & 49.03 & 14.50 & 473.48 \\
\hline $\mathbf{T}_{\mathbf{3}}$ & 87.26 & 4.86 & 11.43 & 60.65 & 15.93 & 643.45 \\
\hline $\mathbf{T}_{\mathbf{4}}$ & 94.55 & 5.73 & 12.16 & 64.07 & 16.10 & 686.99 \\
\hline $\mathbf{T}_{\mathbf{5}}$ & 72.74 & 3.73 & 9.22 & 41.54 & 12.87 & 356.05 \\
\hline $\mathbf{T}_{\mathbf{6}}$ & 76.89 & 3.82 & 9.67 & 43.88 & 14.16 & 413.81 \\
\hline $\mathbf{T}_{\mathbf{7}}$ & 82.11 & 4.55 & 10.15 & 51.82 & 15.09 & 520.78 \\
\hline $\mathbf{T}_{\mathbf{8}}$ & 85.03 & 4.74 & 10.88 & 56.23 & 15.65 & 586.07 \\
\hline $\mathbf{T}_{\mathbf{9}}$ & 61.38 & 1.93 & 8.19 & 35.18 & 11.43 & 267.80 \\
\hline $\mathbf{S E m} \mathbf{(} \mathbf{+}$ & 0.8660 & 0.0076 & 0.0627 & 0.4194 & 0.2546 & 1.3472 \\
\hline $\mathbf{C D}(\mathbf{5 \%})$ & $2.5963 * *$ & $0.0229 * *$ & $0.1880^{* *}$ & $1.2575 * *$ & $0.7633^{* *}$ & $4.0388^{* *}$ \\
\hline
\end{tabular}

* $\mathrm{T}_{1}$-FYM @ 25t/ha, $\mathrm{T}_{2}$ - FYM @ 50t/ha, $\mathrm{T}_{3}$-Poultry manure @ 1t/ha, $\mathrm{T}_{4}$-Poultry manure @ 2t/ha, $\mathrm{T}_{5}$-Mustard cake @ 0.75 t/ha, $\mathrm{T}_{6}$ - Mustard cake @ $1.5 \mathrm{t} / \mathrm{ha}, \mathrm{T}_{7}$-Vermicompost @ $2.5 \mathrm{t} / \mathrm{ha}, \mathrm{T}_{8}$-Vermicompost @ 5 t/ha, $\mathrm{T}_{9}$-Control 
Table.2 Effect of organic manures on yield and yield attributing parameters of Mango ginger (Curcuma amadaRoxb.)

\begin{tabular}{|c|c|c|c|c|c|c|}
\hline Treatments & $\begin{array}{c}\text { Length } \\
\text { of } \\
\text { clumps } \\
\text { (cm) }\end{array}$ & $\begin{array}{c}\text { No. of } \\
\text { mother } \\
\text { rhizome }\end{array}$ & $\begin{array}{c}\text { No. of } \\
\text { primary } \\
\text { finger }\end{array}$ & $\begin{array}{c}\text { No. of } \\
\text { secondary } \\
\text { finger }\end{array}$ & $\begin{array}{c}\text { Yield/ } \\
\text { plant } \\
\text { (gm) }\end{array}$ & $\begin{array}{c}\text { Yield/ } \\
\text { hectare } \\
\text { (t/ha) }\end{array}$ \\
\hline $\mathbf{T}_{\mathbf{1}}$ & 20.95 & 1.58 & 3.46 & 14.66 & 339.21 & 27.13 \\
\hline $\mathbf{T}_{\mathbf{2}}$ & 21.27 & 1.65 & 3.82 & 15.18 & 353.16 & 28.25 \\
\hline $\mathbf{T}_{\mathbf{3}}$ & 22.63 & 1.82 & 5.74 & 15.87 & 397.88 & 31.83 \\
\hline $\mathbf{T}_{\mathbf{4}}$ & 23.10 & 2.03 & 6.18 & 16.11 & 411.02 & 32.88 \\
\hline $\mathbf{T}_{\mathbf{5}}$ & 19.55 & 1.30 & 2.98 & 13.81 & 307.08 & 24.56 \\
\hline $\mathbf{T}_{\mathbf{6}}$ & 20.19 & 1.52 & 3.10 & 14.29 & 326.17 & 26.09 \\
\hline $\mathbf{T}_{\mathbf{7}}$ & 21.48 & 1.71 & 4.13 & 15.45 & 373.69 & 29.89 \\
\hline $\mathbf{T}_{\mathbf{8}}$ & 21.72 & 1.78 & 4.61 & 15.74 & 384.52 & 30.76 \\
\hline $\mathbf{T}_{\mathbf{9}}$ & 16.86 & 0.46 & 2.36 & 4.91 & 144.23 & 11.53 \\
\hline $\mathbf{S E m} \mathbf{( + )}$ & 0.8389 & 0.0192 & 0.0168 & 0.4082 & 0.8553 & 0.5000 \\
\hline $\mathbf{C D}(\mathbf{5 \%})$ & $2.5149 * *$ & $0.0577^{* *}$ & $0.0505^{* *}$ & $1.2239^{* *}$ & $2.5641^{* *}$ & $1.4990^{* *}$ \\
\hline
\end{tabular}

*T $\mathrm{T}_{1}$-FYM @ 25t/ha, $\mathrm{T}_{2}$ - FYM @ 50t/ha, $\mathrm{T}_{3}$-Poultry manure @ 1t/ha, $\mathrm{T}_{4}$ - Poultry manure @ 2t/ha, $\mathrm{T}_{5}$-Mustard cake @ 0.75 t/ha, $\mathrm{T}_{6}$ - Mustard cake @ $1.5 \mathrm{t} / \mathrm{ha}, \mathrm{T}_{7}$-Vermicompost @ $2.5 \mathrm{t} / \mathrm{ha}, \mathrm{T}_{8}$-Vermicompost @ 5 t/ha, $\mathrm{T}_{9}$-Control

Table.3 Effect of organic manures on quality parameters of Mango ginger (Curcuma amada Roxb.)

\begin{tabular}{|c|c|c|}
\hline Treatments & Oleoresin $(\mathbf{\%})$ & Curcumin $(\%)$ \\
\hline T1 & 5.94 & 1.10 \\
\hline T2 & 6.03 & 1.22 \\
\hline T3 & 6.01 & 1.06 \\
\hline T4 & 6.28 & 1.26 \\
\hline T5 & 5.69 & 0.61 \\
\hline T6 & 5.82 & 0.72 \\
\hline T7 & 6.23 & 1.19 \\
\hline T8 & 6.52 & 1.34 \\
\hline T9 & 4.66 & 0.48 \\
\hline SEm $(\mathbf{+})$ & 0.0116 & 0.0077 \\
\hline CD( 5\%) & $0.0347^{* *}$ & $0.0231^{* *}$ \\
\hline
\end{tabular}

*T $\mathrm{T}_{1}$-FYM @ 25t/ha, $\mathrm{T}_{2}$ - FYM @ 50t/ha, $\mathrm{T}_{3}$-Poultry manure @ 1t/ha, $\mathrm{T}_{4}$ - Poultry manure @ 2t/ha, $\mathrm{T}_{5}$-Mustard cake @ 0.75 t/ha, $\mathrm{T}_{6}$ - Mustard cake @ $1.5 \mathrm{t} / \mathrm{ha}, \mathrm{T}_{7}$-Vermicompost @ $2.5 \mathrm{t} / \mathrm{ha}, \mathrm{T}_{8}$-Vermicompost @ $5 \mathrm{t} / \mathrm{ha}, \mathrm{T}_{9}$-Control

\section{Quality parameters}

The observations recorded on quality parameters such as oleoresin (\%) and curcumin (\%) indicated that application of organic manures significantly improved the quality aspects of Mango ginger, with respect to increased oleoresin (\%) and curcumin (\%) as compared to control (Table 3). Application of vermicompost @ 5t/ha $\left(\mathrm{T}_{8}\right)$ recorded highest oleoresin $(6.52 \%)$ and curcumin $(1.34$ $\%)$ content. The minimum oleoresin $(4.66 \%)$ 
and curcumin $(0.48 \%)$ content were recorded in Control $\left(\mathrm{T}_{9}\right)$.

It is concluded from this work that apart from improving macronutrient availability, poultry manure reduced soil bulk density and enhanced its moisture content. These improvements led to significant increases in growth and yield attributes of mango ginger.

\section{Acknowledgement}

The authors duly acknowledge the AICRP on Spices (Voluntary centre), BCKV, Mohanpur, Nadia for providing support and facilities for successfully conducting this experiment.

\section{References}

Achut, S. G. and Bandyopadhyaya, C. (1984). Characterization of mango like aroma in Curcuma amada Roxb. Journal of Agricultural and Food Chemistry., 32: 57-59.

Adesodun, J. K., Mbagwu, J. S. C. and Oti, N. (2005). Distribution of carbon, nitrogen and phosphorus in waterstable aggregates of an organic waste amended Ultisol in southern Nigeria. Bioresource Technology., 96(4): 509516.
Gomez, K. A. and Gomez, A. A. (1984). Statistical procedures for agricultural research. John Wiley \& Sons.

Kirtikar, K. R., Basu, B. D. (1984). Indian Medicinal Plants, Bishen Singh Mahendra Pal Singh, Dehra Dun, 4(2): 2422.

Nadkarni, K. M. (1954). The Indian Materia Medica. Popular Book depot: Bombay, 412.

Rao, A. S., Rajanikanth, B. and Seshadri, R. (1989). Volatile aroma components of Curcuma amada Roxb. Journal of agricultural and food chemistry., 37(3): 740-743.

Sasikumar, B. (2005). Genetic resources of Curcuma: diversity, characterization and utilization. Plant Genetic Resources., 3(2): 230-251.

Stirling, G. R. (1989). Organic amendments for control of root-knot nematode (Meloidogyne incognita) on ginger. Australasian Plant Pathology., 18(2): 39-44.

Stirling, G. R. and Nikulin, A. (1998). Crop rotation, organic amendments and nematicides for control of root-knot nematodes (Meloidogyne incognita) on ginger. Australasian Plant Pathology., 27(4): 234-243.

\section{How to cite this article:}

Anupam Pariari, C.S. Karthik and Sarthak Bhattacharya. 2019. Effect of Organic Manures on Growth, Yield and Quality of Mango Ginger (Curcuma amada Roxb.) in the Gangetic Alluvial Plains of West Bengal. Int.J.Curr.Microbiol.App.Sci. 8(11): 1030-1034.

doi: https://doi.org/10.20546/ijcmas.2019.811.121 